\title{
Oral health assessment from the perspective of the municipal manager
}

\author{
Avaliação da saúde bucal na ótica do gestor municipal
}

Lúcia Maria Lima Lemos de MELO'

Suzely Adas Saliba MOIMAZ1

Cléa Adas Saliba GARBIN ${ }^{1}$

Artênio José Ísper GARBIN ${ }^{1}$

Nemre Adas SALIBA'

\section{ABSTRACT}

\section{Objective}

The aim of this study was to conduct a situational diagnosis related to the organization of oral health services in 40 municipalities of São Paulo State, Brazil.

\section{Methods}

This is a cross-sectional, quantitative and qualitative, descriptive study performed through document analysis and application of a semistructured questionnaire to oral health coordinators, in 2014. The following items were defined: dental infrastructure, access and regulation, work organization and assessment strategies. Although the Basic Health Unit is the main gateway to the system, dental care was also conducted in schools; the main service access of the population was the spontaneous demand and there have been production data inconsistencies in the information systems.

\section{Results}

It was observed that, $60 \%$ answered that the health planning process included oral health; $47.5 \%$ performed risk assessment; $47.5 \%$ did not perform evaluation and monitoring of results.

\section{Conclusion}

It is concluded that municipalities present different moments in the structuring of the service and that managers should improve the access organization, the work process and service evaluation in order to consolidate the universality and comprehensiveness of health care.

Indexing terms: Health evaluation. Oral health. Primary health care.

\section{RESUMO}

Objetivo

Realizar um diagnóstico situacional relacionado à organização dos serviços de saúde bucal de 40 municípios do Estado de São Paulo, Brasil.

\section{Métodos}

Trata-se de um estudo transversal, quanti-qualitativo, descritivo, realizado em 2014, por meio de análise documental e aplicação de um questionário semiestruturado nos coordenadores de saúde bucal. As seguintes dimensóes foram definidas: infraestrutura odontológica, acesso e regulação, organização do processo de trabalho e estratégias de avaliação. Apesar da Unidade Básica de Saúde ser a principal porta de entrada para o Sistema, o atendimento odontológico ainda era realizado em escolas; a principal forma de acesso da população aos serviços foi a demanda espontânea e havia inconsistências nos dados de produção nos sistemas de informações.

\section{Resultados}

Do total, $60 \%$ responderam que o processo de planejamento em saúde envolveu a área de saúde bucal; 47,5\% realizavam avaliação de risco; $47,5 \%$ não realizavam avaliação e o acompanhamento dos resultados alcançados.

\section{Conclusão}

Conclui-se que os municípios apresentam diferentes momentos na estruturação do serviço e que os gestores devem aprimorar a organização do acesso, do processo de trabalho e da avaliação dos serviços para a consolidação da universalidade e integralidade da atenção em saúde.

Termos de indexação: Avaliação em saúde. Saúde bucal. Atenção primária à saúde.

\footnotetext{
${ }^{1}$ Universidade Estadual Paulista Júlio de Mesquita Filho, Faculdade de Odontologia, Departamento de Odontologia Infantil e Social. Rua José Bonifácio, 1193, 16015-050, Vila Mendonça, Araçatuba, SP, Brasil. Correspondência para / Correspondence to: LMLL MELO. E-mail: <lumalim1@terra com.br>.
} 


\section{INTRODUCTION}

After almost three decades of the institutionalization process of the Unified Health System (UHS), it is observed that its deployment and implementation has improved mainly concerning decentralization and municipalization of health service actions. The decentralization process has brought better UHS interaction with the country's social, political and administrative reality and with its regional specificities'.

A relevant milestone was the emergence of the Family Health Strategy (FHS), in the early 1990s, which proposed the organization of municipal health systems thus fulfilling UHS principles ${ }^{2}$. Territory and its population, teamwork and intersectoriality are fundamental axes of this conception and home visits, one of its main strategies, aims to expand service access as well as create links with the population ${ }^{3}$.

In this context, Oral Health was inserted in the Family Health Strategy, advocating a participative dental model role in the Health Unit, in the Family and also in the Community, allowing the population better oral health access, as well as quality improvement in the services offered ${ }^{4}$.

In 2000, the publication of 1444 Decree officialized the incorporation of the Oral Health Teams $(\mathrm{OHT})$ in the FHS. Currently it is in effect, 2488 Decree, dated October 21st, 20115, which approves the National Primary Care Policy, providing guideline and standard revision for the organization of Primary Care, for the Family Health Strategy (FHS) and the Program Of Community Health Agents (PCHA), as well. It must be emphasized that the Oral Health Team inserted in the Family Health strategy represents the possibility of creating a new space of practices and also provides relationship enhancement towards the work process reorientation ${ }^{6}$. Offices, previously set in schools, were relocated to the basic network; providing greater oral health integration actions towards other programs. This way, the population groups excluded from their basic rights began to benefit from specific programmes ${ }^{7}$.

However, it can be observed that the history of the dental surgeon 'practices (DS) is still characterized by individual and merely clinical intervention for a reduced clientele, occurring by spontaneous demand.

Taking into consideration that due to important public policy initiatives a decrease in the number of municipalities without dental care resources ${ }^{8}$ has occurred along with regularly providing financial benefits for Oral Health in Family Health, Dental Specialties Centers (DSCs) and Regional Dental Prosthesis Laboratories (RDPL), it is crucial to verify whether there has been any real change in the model of practices at the place itself ${ }^{9}$, both in the population's health status and also in terms of knowledge and behavior derived from the practices developed ${ }^{10}$.

In this scenario, the RDs are as follows: Regional Health Departments (RHS), which belong to the Health Secretariat, in charge of contributing to the quality of life of the population of the respective regions, coordinating, articulating, organizing and managing the regional point of use ${ }^{11}$. The proximity of RDS to municipal management enables them to have a precise idea of the real work developed as well as to implement actions that can contribute to the improvement of the Health Care assistance to user-facing service.

Thus, in this study, a situational diagnosis was performed aiming at the organization of primary care oral health service of 40 municipalities (the RDs II area) in the city of Araçatuba, São Paulo State, Brazil.

\section{METHODS}

This is a quantitative-qualitative, descriptive study which sample consisted of oral health coordinators from 40 municipalities, within the area of the Regional Health Department (RHD) Araçatuba II, State of São Paulo, Brazil. The aim of the research was to evaluate the coordinators' self-knowledge towards oral health management.

The municipal coordinators of oral health are dental surgeons and $95 \%$ of them are officially nominated by the municipal manager. They were informed about the purpose of the study and signed a Free and Informed Consent Term. The study was approved by the Research Ethics Committee of the Faculty of Dentistry of Araçatuba (FOA / UNESP), under the process number 32535814.3.0000.5420. A pilot study was carried out to in order to validate the collection instrument. The data were collected through documentary analysis of the indicators in the 2013 Sispacto(a pact system), and the application of a semi-structured and self-administered questionnaire showing open and closed questions proposed by the managers at a meeting held at RHD II headquarters and then processed using the program Microsoft Excel 2008 for quantitative variables.

The Content Analysis method was used for the open questions, based on the analysis of the central idea, 
preserving the information expressed in the answers of the subjects involved, confronting the interviewees' statements with the current literature, based on scientific articles, ministerial decrees and others.

The following priority items were established: dental infrastructure, primary care access and regulation, organization of the work process and evaluation strategies. Regarding the dental infrastructure description, the following was analyzed: the number of dental offices existing in schools, a team composed of Oral Health Auxiliary (OHA) and Oral Health Technician (OHT), the existence of a Center of Dental Specialties (CDS), Regional Laboratories Of Dental Prosthesis (RLDP) and Oral Health Teams (OHT) implanted in the Family Health Strategy (FHS). Flow and risk screening were addressed for primary care access and regulation.

Planning and teamwork were analyzed as important work organization items. Evaluation strategies focused on the epidemiological diagnoses, implementation and monitoring of the indicators, together with the participation of the population.

In accordance with the 2006 Management Pact ${ }^{1}$ and regionalization, the II RHD was organized in three regions, known as: Health Region of the Lakes, Central and Consortia, with 12, 11 and 17 municipalities, respectively.

The results of the study were discussed and proposed at the II RHD headquarters with the municipal oral health coordinators through three workshops, one in each Health Region, aiming to empower change needs based on the literature and the institutionalized Guidelines of the State of São Paulo Department of Health and Guidelines of the National Oral Health Policy of the Ministry of Health.

\section{RESULTS}

It was observed that dental clinic care was still performed in schools in $62.5 \%$ of the municipalities; spontaneous demand showed to be the main form of treatment access in 95\%. The results also showed impairment in delimiting the population access in the assigned area and finally that $40 \%$ of the planning process did not involve the oral health area.The results were described as follows: dental infrastructure description, primary care access and regulation, work process organization and evaluation strategies. The lack of information about professionals' Collective Health studies as well as their time of action in Oral Health management restricts the present research.

\section{Dental infrastructure description}

Although, clinical dental care is still performed in schools, the municipalities also showed that the Basic Health Unit has been the main gateway for the Unified Health System, with the highest number of dental professionals. (Table 1). In 23 municipalities, the oral health coordinators reported insufficient human resources in order to carry out dental work and that there is maladjustment of managerial functions and attendance activities.

Of all the municipalities, 39 of them present Oral Health Care $(\mathrm{OHC})$ assistants, however $52.45 \%$ of these professionals do not have a proper education degree in this area. Only in 3 municipalities the Oral Health Technicians $(\mathrm{OHT})$ present a training course and in 2 municipalities they work as assistants. The Oral Health Team (OHT) in the Family Health Strategy (ESF) is present in $82.5 \%$ of the municipalities.

Six specialized dentistry centers (SDC) and 20 regional dental prosthesis laboratories (RDPL) have been implemented in the specialized care.

Table 1. Number of dentists in 40 municipalities in the State of São Paulo, according to attendance place, 2014.

\begin{tabular}{lcc}
\hline Attendance place & $\mathbf{n}$ & \% \\
\hline HBU (without HFS) & 105 & 33.0 \\
HFS & 82 & 25.8 \\
Schools & 73 & 23,0 \\
DSC & 34 & 10.7 \\
Emergency & 11 & 3.4 \\
Hospitals & zero & 0.0 \\
Other places & 13 & 4.1 \\
Total & 318 & 100 \\
\hline
\end{tabular}

\section{Access and regulation}

The interviewees mentioned the following ways of seeking patients for dental treatment: program groups, referrals by the Community Health Agents and through the use of risk criteria. However, the main form of access is the spontaneous demand in 95\% with later scheduling, and the emergency cases are attended immediately.

Risk screening is not performed in 52.5\% of municipalities

\section{Organization of the work process}

The planning processes do not involve the oral health area in 16 municipalities. As a consequence, the BSEs are not integrated with the other health actions of the Basic Health Units (BHU), a feature identified in 12 municipalities. The integration, in the majority, corresponded to the actions performed with children and pregnant women; 
followed by hypertension and diabetes groups and lower performance in the groups of adolescents and people with disabilities (Table 2).

Table 2. Oral health actions in 40 municipalities of the State of São Paulo, 2014: Specific groups.

\begin{tabular}{llc}
\hline Specific groups & N & $\%$ \\
\hline Children & 32 & 80.0 \\
Pregnant women & 32 & 80.0 \\
Hypertensive patients & 17 & 42.5 \\
Diabetic patients & 17 & 42.5 \\
Adolescents & 15 & 37.5 \\
Special needs patients & 11 & 27.5 \\
Others & 10 & 25.0 \\
\hline
\end{tabular}

\section{Evaluation strategies}

When questioned whether they knew the oral health indicators evaluated in the municipality, $90 \%$ of the managers answered affirmatively. The mentioned indicators were: first programmed dental appointment, DMFT indices, population coverage estimated by BSEs, average number of supervised dental brushings, proportion of exodontia in relation to outpatient procedures.

Epidemiological survey data are present in 34 municipalities, however, they are not used for planning actions and activities in 18 of them and the assessment and monitoring of the results achieved are not performed by 19 municipalities. Regarding listening to the population's satisfaction in the Dentistry area, $60 \%$ answered affirmatively (Table 3).

Table 3. Description of the work process in oral health actions in 40 municipalities of the State of São Paulo, 2014

\begin{tabular}{|c|c|c|c|c|c|c|c|c|}
\hline \multirow[t]{2}{*}{ Questions } & \multicolumn{2}{|c|}{ Yes } & \multicolumn{2}{|c|}{ No } & \multicolumn{2}{|c|}{ No information } & \multicolumn{2}{|c|}{ Total } \\
\hline & $\mathbf{n}$ & $\%$ & $\mathbf{n}$ & $\%$ & $\mathbf{N}$ & $\%$ & $\mathrm{n}$ & $\%$ \\
\hline $\begin{array}{l}\text { Does the municipality have BSES } \\
\text { deployed in the FHS? }\end{array}$ & 33 & 82.5 & 7 & 17.5 & 0 & 0 & 40 & 100 \\
\hline $\begin{array}{l}\text { Is there integration, in the Health } \\
\text { Unit, between oral health and } \\
\text { other health actions? }\end{array}$ & 28 & 70 & 12 & 30 & 0 & 0 & 40 & 100 \\
\hline $\begin{array}{l}\text { Does the dental coordinator } \\
\text { participate in the municipality } \\
\text { Health planning o? }\end{array}$ & 24 & 60 & 16 & 40 & 0 & 0 & 40 & 100 \\
\hline $\begin{array}{l}\text { Are there enough human } \\
\text { resources for the municipality } \\
\text { dental work? }\end{array}$ & 17 & 42.5 & 23 & 57.5 & 0 & 0 & 40 & 100 \\
\hline $\begin{array}{l}\text { Is there enough dental } \\
\text { equipment to better assist the } \\
\text { population? }\end{array}$ & 24 & 60 & 16 & 40 & 0 & 0 & 40 & 100 \\
\hline $\begin{array}{l}\text { Is there a population listening- } \\
\text { sharing procedure used by that } \\
\text { the municipality regarding the } \\
\text { dental area? }\end{array}$ & 24 & 60 & 15 & 37.5 & 1 & 2.5 & 40 & 100 \\
\hline $\begin{array}{l}\text { Do you know which are the Oral } \\
\text { Health indicators used in the } \\
\text { municipality? }\end{array}$ & 36 & 90 & 4 & 10.0 & 0 & 0 & 40 & 100 \\
\hline $\begin{array}{l}\text { Are there epidemiological survey } \\
\text { data in Oral Health? }\end{array}$ & 34 & 85 & 6 & 15 & 0 & 0 & 40 & 100 \\
\hline $\begin{array}{l}\text { Are the municipality conducting } \\
\text { risk screening? }\end{array}$ & 19 & 47.5 & 21 & 52.5 & 0 & 0 & 40 & 100 \\
\hline Are standards set to guide BSEs? & 10 & 25 & 30 & 75 & 0 & 0 & 40 & 100 \\
\hline $\begin{array}{l}\text { Are epidemiological data used to } \\
\text { plan actions / activities? }\end{array}$ & 22 & 55 & 18 & 45 & 0 & 0 & 40 & 100 \\
\hline $\begin{array}{l}\text { Do they perform evaluations } \\
\text { and follow-up of the results } \\
\text { achieved? }\end{array}$ & 20 & 50 & 19 & 47.5 & 1 & 2.5 & 40 & 100 \\
\hline $\begin{array}{l}\text { Is the population encouraged to } \\
\text { participate in actions in the area } \\
\text { of Dentistry? }\end{array}$ & 29 & 72.5 & 11 & 27.5 & 0 & 0 & 40 & 100 \\
\hline
\end{tabular}

\section{DISCUSSION}

Despite the fact that the Basic Health Unit presents the highest concentration of dental surgeons, clinical dental care is still present in the schools, which characterizes a model of care similar to the one introduced in the 1950s by the Special Public Health Service ( SPHS), a curative-restorative approach which aimed at schoolchildren from 6 to 14 years of age ${ }^{12}$. 
Oral Health actions seem to be resistant to familyoriented, which is, evidenced in the following:

"I would like to deploy dental office in school again and have more dentists in the unit."

It has been noticed that children transmit the dental knowledge acquired at school to their parents, changing their oral health routine ${ }^{13}$. Nonetheless reordering of the dental practice work, with sensitive changes in the oral health-disease process is a crucial need.

It is important to raise the managers' awareness emphasizing that the focus should be the family, the collective and not restricted to certain age groups or exclusively to certain population groups. It is crucial to highlight that the public dental service is not limited to clinical care, but it also includes community action, epidemiological surveys, preventive actions and health education as well as groups with differentiated needs ${ }^{14-15}$.

The need for an increase in the number of professionals was justified by the presence of a floating population, characteristic of the HDR II region, composed of sugarcane workers, field settlements, penitentiaries, features which change the epidemiological, population and social profile of the municipalities.

"... The floating population counts for almost 50\% and many do not even reside in the municipality."

It is of utmost importance that municipalities delimit the geographical territory of the floating population in order to achieve universal and equitable access.

The lack of establishment of hours for the management and service activities was well evidenced in the following saying:

"I make home visits, planning, coordination, attendance in the city and on the site, brushing in schools and night care."

Health Coordinators show demotivation due to not having a differentiated remuneration for the management, in most cases. It is important to highlight the value of professionals who are engaged in managerial activities on a daily basis setting a real proposal for the establishment of a job, career and salary plan specific to their political-managerial framework ${ }^{16}$.

Regarding assistance care, oral health teams inserted in family health may be qualified in modality I or II, with the mandatory presence of $\mathrm{BHA}$ and $\mathrm{BHT}$, respectively. However, it was verified that there is low qualification of these professionals together with their role shift. Thus, for them it is a challenge to work in the routine of the oral health team of the Unified Health
System, weakening the provision of services in oral health care to the users ${ }^{17}$.

Regarding the insertion of the OHT into the FHT, it is important to convince the municipal manager about the advantages of converting the traditional model of dental care services into oral health ${ }^{18}$. It is a fact that oral health incorporated into the FHT is a meaningful advance and a great challenge, a possibility of increasing coverage, effectiveness in responding to the demands of the population and reaching collective-oriented measures.

The greatest gains are in the fields of teamwork, managers and users' relationships which can imply in a new oral health care approach with action in all stages of the life cycle, using the family as agent promoter ${ }^{19}$. In addition, one of WHO's annual reports praises the Brazilian experience in maintaining the Unified Health System, guided by Family Health ${ }^{20}$.

Regarding referential care, it should be observed that the expansion of the secondary and tertiary care assistance network did not follow the basic care services growth in the dental sector ${ }^{18}$. This is aggravated by the existence of Dental Specialties Centers (DSC) and Regional Dental Prosthesis Laboratories (RDPL) that only meet the demand of the municipality itself. Access has been better, either by the organization actually carried out or by the team expansion, however secondary and tertiary care is not guaranteed.

It is necessary to characterize the whole territory and re-discuss pacts in the health regions, also known as the Regional Interagency Commission (RIC), in order to increase access throughout the collegiate. The RIC is where decision-making and prioritization among managers happens, contributing to the reduction of inequalities bringing equity and strength so that municipalities may play their managerial roles ${ }^{21}$.

This can be used to better discuss the implantation of regionally oriented DSCS (not just a municipal reference), providing greater coverage of specialized oral health actions.

It was observed that scheduled access is not a reality for municipalities, as the following says:

"The patient looks for BHU and if it is possible, the appointment is immediately already scheduled, if the Unit is full, a waiting list is prepared once it is the time the schedule is done. In case of urgency, the attendance is done on the same day."

"The patient arrives in the unit and the receptionist gives the options of dentists and the patient is scheduled 
with the chosen one. The patient who is in pain is treated the same day, and then it is scheduled for the following treatment"

In order to welcome spontaneous demand, access with equity needs to be a constant concern. Equity is based on the premise that different or unequal ones must be treated differently according to their needs, correcting and / or avoiding unfair and negative differentiations. The order of arrival is not the main criterion for the care of the cases, but its severity or the suffering of the patient. In this sense, priority is given to attending to any emergency, when it is causing pain or suffering to the user. Urgency is an important moment for meeting individuals with greater vulnerability ${ }^{22-23}$.

One of the tools for flow rationalization is the use of risk screening. However, it is not used by $52.5 \%$ of municipalities. It allows the identification of individuals, considering the degree of risk to different oral diseases and insertion into specific actions. They can be performed in the following situations: in the health units with the constituted groups, in the community, in the homes for planning, organization and care referral and in appointment for oral cancer diagnosis ${ }^{24}$.

The flow rationalization, which provides the regulation of the work process based on the spontaneous demand, is not performed by most municipalities, therefore it is fundamental to create flows that imply resolute actions of health teams, focused on welcoming, informing, attending and directing ${ }^{18}$ thus providing oral health actions where child, adolescent, adult, elderly and I or by condition of life are fully accessed and treated.

The greater integration corresponded to the actions performed with children and pregnant women. The mother plays a fundamental role in the behavioral patterns learned during early childhood, and educationalpreventive actions with pregnant women qualify their health and become essential to introduce good habits since the beginning of the child's $\operatorname{life}^{18}$. However, expanding public dental care beyond the traditional maternal-infant group has been an enormous difficulty for the health network, since resources for this purpose, although increasing, are not sufficient to immediately meet all the potential needs of the population ${ }^{15}$.

Non-integration with other professional categories brings isolation components of the oral health area within the unit and can be identified in the Oral Health Coordinator's talk, as observed below:
"I develop my own strategy, since I work in Family Health and take care of the bureaucratic part but regarding the dental team, I do not participate in decisions and appointments."

In the organization of health actions and services, planning creates the possibility of understanding the reality, the main problems and needs of the population. Individually, intuitively and little systematized planning, without institutional socialization of the projects developed cannot bring good results. Planning needs to be carried out in a language understood and shared by all, aiming at partnership at all times ${ }^{14}$, in order to provide effective and resolute actions. If public health interventions are introduced without strategic planning to allow the benefit universalization or yet to direct additional resources to the neediest groups, they end up having the undesirable effect of widening health inequalities ${ }^{15}$.

The indicators mentioned as evaluated by the managers were: first programmed dental appointment, DMFT indices, population coverage estimated by OHTs, average number of supervised dental brushings, and proportion of exodontia in relation to outpatient procedures. The last three indicators mentioned in most of the answers are part of the 2013 Sispacto System (Pact System). It is of the utmost importance that the management uses indicators, besides those requested by the federal government, important features for organization, monitoring and evaluation of the local work process. If the manager understands that he needs to know only what the official government asks him, then his need is determined by that ${ }^{25}$.

Sispacto 2013 indicator analysis brings inconsistency in the registration of procedures in the Information System that may have been caused by deficiencies, excesses or lack of releases. In the National Register of Health Establishments (NRHE), it was verified the lack of registration of the professionals who worked in Primary Care because they were registered in Dental Specialties Centers, a fact which may interfere with the result of the Indicator Estimated Population Coverage of Oral Health Teams. Another error is the absence or deficiency in the production launches of the Collective Action of Supervised Brushing. The Proportion of Exodontias in Relation to Ambulatory Procedures indicator presents reduction or increase, which may characterize the health model practiced by the municipality, whether it is health promotion or mutilatory. When the municipality 
implants OHT in the FHT, it allows access of the population with greater needs to the dental treatment and can increase in the proportion of exodontia.

Therefore, it is important that workers and managers understand the use of information systems used with reliable data records, in the planning and monitoring processes of health services.

A positive aspect was that most of the Coordinators did report the use for planning of data coming from Oral Health epidemiological surveys such as: caries, periodontal disease, dental fluorosis, oral lesions and the need for prosthesis.

When questioned about the types of parameters used, the service directed to the students is evidenced in the response:

"A parameter is established in schools for children at 5 years of age, when they begin their school activities.

In order to increase and qualify the assistance, it is recommended that $75 \%$ to $85 \%$ of the contracted hours be devoted to assistance and $15 \%$ to $25 \%$ to other activities (planning, training and collective activities). The collective educational and preventive activities may be carried out, preferably, by assistant personnel ${ }^{18}$. In addition, community health agents perform oral health education through the School Health Program (SHP). The SHP presents integration strategy and permanent articulation between the policies and actions of education and health with the participation of the school community. Involving FHS and basic education. Among the health actions foreseen in the scope of the SHP is the assessment of oral health and hygiene ${ }^{26}$.

The evaluation process is not commonly used by municipalities and it is important that they are incorporated into $t$ the health service practices, not only for planning but for decision-making as well ${ }^{8}$.

A powerful thinking and transformation tool of the work process is the information system e-SUS Basic Attention ${ }^{27}$ which allows more reliable evaluation results since, the indicators present higher quality and are closer to what is produced daily by the health teams. The e-UHS strategy refers to the qualified UHS computerization process while searching for an electronic procedures ${ }^{28}$.

Lack of knowledge of local needs in the monitoring and evaluation of activities have impaired adequate dental care for the population, since these practices are indispensable tools for planning and organizing oral health actions ${ }^{8}$.

Although Dentistry has achieved preventive and curative technological advances over the years, the process of evaluating services is still not understood as a management tool ${ }^{29}$.

Actions of oral health users' evaluation is a present measure in most municipalities. The perception of the user is of crucial importance when measuring the actions that have been developed in the health sector and it is a guiding and planning tool of the service provided ${ }^{30}$.

Thus, this study has contributed to the evaluation of the different care arrangements deployed in the municipalities. It made it possible to recognize that after 30 years of implementation of the UHS, oral health teams still have difficulties to perform actions as recommended by the National Oral Health Policy.

\section{CONCLUSION}

The surveyed municipalities present different moments in the structuring of the service and there has been advances that deserve to be reinforced and shared, however, adequate criteria in oral health management have not been used in order to improve the organization of access, work process and evaluation. Managers and members of oral health teams need to be trained in order to reorganize, monitor and evaluate oral health actions in primary care, according to the permanent education, based on the universality and integrality of care.

\section{Collaborators}

SAS MOIMAZ and LMLL MELO participated in the design, analysis and interpretation of data, essay writing, critical review and approval of the version to be published. CAS GARBIN, AJI GARBIN and NA SALIBA participated in the analysis and interpretation of the data, essay writing, critical review and approval of the version to be published. 


\section{REFERENCES}

1. Brasil. Ministério da Saúde. Portaria n. 399, de 22 de fevereiro de 2006. Divulga o Pacto pela Saúde 2006 - Consolidação do SUS e aprova as Diretrizes Operacionais do Referido Pacto. Diário Oficial da Republica Federativa do Brasil, Brasília: Ministério da Saúde; 2006 [citado 2014 Sep 12]. Disponível em: <http://www.saude. mppr.mp.br/modules/conteudo/conteudo.php?conteudo=48>.

2. Starfield B. Atenção primária: equilíbrio entre necessidades de saúde, serviços e tecnologias. Brasília: Ministério da Saúde; 2002.

3. Brasil. Ministério da Saúde. Diretrizes da Política Nacional de Saúde Bucal. Brasília: Ministério da Saúde; 2004 [citado 2014 Sep 12]. Disponível em: <http://189.28.128.100/dab/docs/publicacoes/ geral/diretrizes_da_politica_nacional_de_saude_bucal.pdf>.

4. Pimentel FC, Albuquerque PC, Martelli PJL, Souza WV, Acioli RML. Caracterização do processo de trabalho das equipes de saúde bucal em municípios de Pernambuco, Brasil, segundo porte populacional: da articulação comunitária à organização do atendimento clínico. Cad Saúde Pública. 2012;28(Suppl):s146-s157. doi: 10.1590/ S0102-311X2012001300015

5. Brasil. Ministério da Saúde. Portaria n. 2.488, de 21 de outubro de 2011. Aprova a Política Nacional de Atenção Básica, estabelecendo a revisão de diretrizes e normas para a organização da Atenção Básica, para a Estratégia Saúde da Família (ESF) e o Programa de Agentes Comunitários de Saúde (PACS). Diário Oficial da Republica Federativa do Brasil, Brasília (DF); 2011 [citado 2014 Sep 12]. Disponível em: <http://www.saude.mt.gov. br/upload/legislacao/2488-[5046-041111-SES-MT].pdf>.

6. Brasil. Ministério da Saúde. Portal da Saúde. Brasil Sorridente: estratégia saúde da família. Equipe de Saúde Bucal [citado 2014 Sep 12]. Disponível em: <http://dab.saude.gov.br/portaldab/ape_ brasil_sorridente.php?conteudo=equipes $>$.

7. Frazão P. Vinte anos de Sistema Único de Saúde: avanços e desafios para a saúde bucal. Cad Saúde Pública. 2009;25(4):712713. doi: 10.1590/S0102-311X2009000400001

8. Pimentel FC, Martelli PJL, Júnior JLACA, Acioli RML, Macedo CLSV. Análise da atenção à saúde bucal na Estratégia de Saúde da Família do Distrito Sanitário VI, Recife (PE). Ciênc Saúde Coletiva. 2010;15(4):2189-2196. doi: 10.1590/S141381232010000400033

9. Mattos GCM, Ferreira EF, Leite ICG, Greco RM. A inclusão da equipe de saúde bucal na Estratégia Saúde da Família: entraves, avanços e desafios. Ciênc Saúde Coletiva. 2014;19(2):373-382. doi: 10.1590/1413-81232014192.21652012

10. Donabedian A. The role of outcomes in quality assessment and assurance. QRB Qual Rev Bull. 1992 Nov;18(11):356-60.

11. São Paulo (Estado). Decreto n. 51.433, de 28 de dezembro de 2006. Cria unidade na Coordenadoria de Regiões de Saúde, da Secretaria da Saúde, altera a denominação e dispõe sobre a reorganização das Direções Regionais de Saúde e dá providências correlatas. Diário Oficial do Estado de São Paulo 2006; 29 dez [citado 2014 Sep 12]. Disponível em: <http://www.al.sp.gov.br/ repositorio/legislacao/decreto/2006/decreto-51433-28.12.2006. html>.

12. Brasil. Ministério da Saúde. Saúde Bucal. Brasília: Ministério da Saúde; 2008.
13. Garbin C, Garbin A, Dos Santos K, Lima D. Oral health education in schools: promoting health agents. Int J Dent Hyg. 2009 Aug;7(3):212-6. doi: 10.1111/j.1601-5037.2009.00394.x

14. Roncalli AG. A organização da demanda em serviços públicos de saúde bucal: universalidade, equidade e integralidade em saúde bucal coletiva [tese]. Araçatuba: Unesp; 2000.

15. Antunes JLF, Narvai PC. Políticas de saúde bucal no Brasil e seu impacto sobre as desigualdades em saúde. Rev Saúde Pública. 2010;44(2):360-365. doi: 10.1590/S003489102010005000002

16. Paim JS, Teixeira CF. Configuração institucional e gestão do Sistema Único de Saúde: problemas e desafios. Cienc Saude Coletiva. 2007;12(Suppl):1819-1829. doi: 10.1590/S141381232007000700005

17. Costa AO, Silva LP, Saliba O, Garbin AJl, Moimaz SAS. A participação do auxiliar em saúde bucal na equipe de saúde e o ambiente odontológico. Rev Odontol UNESP. 2012;41(6):371376.

18. Brasil. Ministério da Saúde. Guia Prático do Programa Saúde da Família. Brasília: Ministério da Saúde; 2001 [citado 2015 Jan 14]. Disponível em: <http://189.28.128.100/dab/docs/publicacoes/ geral/guia_pratico_saude_familia_psf1.pdf>.

19. Farfán J, Valenzuela MT. Incorporación de los odontólogos en los procesos de transformación al modelo de salud familiar de la atencion primaria en Chile. Rev Chil Salud Pública. 2014;18(1):7280 .

20. World Health Organization. The world health report 2008 primary health care now more than ever. Geneva: WHO; 2008.

21. São Paulo (Etado). Deliberação CIB 34/2012. Aprova as diretrizes e estratégias para estruturação da Política Estadual de Atenção Básica do Estado de São Paulo. Diário Oficial do Estado de São Paulo; 2012 [citado 2015 Jan 14]. Disponível em: <ftp://ftp.saude. sp.gov.br/ftpsessp/bibliote/informe_eletronico/2012/iels.mai.12/ lels99/E_DL-CIB-34_2012.pdf>

22. Brasil. Ministério da Saúde. Acolhimento à demanda espontânea. Brasília (DF): Ministério da Saúde; 2013 [citado 2015 Jan 14]. Disponível em: <http://www.saude.sp.gov.br/resources/ humanizacao/biblioteca/documentos-norteadores/cadernos_de_ atencao_basica_-_volume_i.pdf>.

23. Brasil. Ministério da Saúde. Organização da Saúde Bucal na Atenção Básica. Brasília: Ministério da Saúde; 2008.

24. São Paulo (Estado). Secretaria de Estado da Saúde de São Paulo. Manual de orientações em saúde bucal para o SUS no âmbito do estado de São Paulo. São Paulo (SP): Secretaria de Estado da Saúde; 2010 [citado 2014 Sep 12]. Disponível em: <http://www. saude.sp.gov.br/resources/ses/perfil/profissional-da-saude/grupotecnico-de-acoes-estrategicas-gtae/saude-bucal/documentostecnicos/manual_de_orientacoes_em_saude_bucal_para_o_sus_ no_ambito_do_estado_de_sao_paulo.pdf>

25. Vidor AC, Fisher PD, Bordin R. Utilização dos sistemas de informação em saúde em municípios gaúchos de pequeno porte. Rev Saude Pública. 2011;45(1): 24-30. doi: 10.1590/S003489102011000100003

26. Brasil. Ministério da Saúde. Decreto 6.286 , de 5 de dezembro de 2007. Institui o Programa Saúde na Escola - PSE, e dá outras 
providências. Diário Oficial da Republica Federativa do Brasil, Brasília (DF); 2007 [citado 2014 Sep 12]. Disponível em: <http:// www.planalto.gov.br/ccivil_03/_ato2007-2010/2007/decreto/ d6286.htm>.

27. Brasil. Ministério da Saúde. Portaria $n^{\circ} 1.412$, de 10 de julho de 2013. Institui o Sistema de Informação e Saúde para a Atenção Básica (SISAB). Diário Oficial da Republica Federativa do Brasil, Brasília (DF); 2013 [citado 2014 Sep 12]. Disponível em: <http:// www.saude.ba.gov.br/dab/arquivos/Portaria_1412\%20jul_13. pdf $>$.

28. Brasil. Ministério da Saúde. Portal da Saúde. e-SUS Atenção Básica [citado 2015 Jul 4]. Disponível em: <http://dab.saude.gov. br/portaldab/esus.php>.

29. Melo LMLL, Moimaz SAS, Garbin CAS, Garbin AJl, Marques BM, Saliba NA. Avaliação do impacto dos programas governamentais em saúde sob a ótica do gestor. Rev Paul Odontol. 2013;36(1): 24- 29.

30. Moimaz SAS, Marques JAM, Saliba O, Garbin CAS, Zina LG, Saliba NA. Satisfação e percepção do usuário do SUS sobre o serviço público de saúde. Physis [Internet]. 2010 Dec [citado 2015 Jul 8];20(4):1419-1440. Disponível em: <http:// www. scielo.br/scielo.php?script=sci_arttext\&pid=S010373312010000400019\&lng=en>. doi: 10.1590/S010373312010000400019

Received on: 16/10/2015

Final version resubmitted on: 7/1/2016

Approved on: 15/2/2016 